\title{
Solar Energy Potential in the Yangtze River Delta Region- A GIS-Based Assessment
}

\author{
Morice R. O. Odhiambo ${ }^{1}\left(\mathbb{D}\right.$, Adnan Abbas ${ }^{1}$, Xiaochan Wang ${ }^{1,2, *}$ and Gladys Mutinda ${ }^{3}(\mathbb{D})$ \\ 1 College of Engineering, Nanjing Agricultural University, Nanjing 210031, China; \\ moriceoluochodhiambo@outlook.com (M.R.O.O.); dr_adnan219@yahoo.com (A.A.) \\ 2 Jiangsu Province Engineering Lab for Modern Intelligent Facilities of Agriculture Technology \& Equipment, \\ Nanjing 210031, China \\ 3 College of Public Administration, Nanjing Agricultural University, Nanjing 210095, China; \\ gladysndungemutinda@outlook.com \\ * Correspondence: wangxiaochan@njau.edu.cn; Tel.: +86-25-58606585
}

check for updates

Citation: Odhiambo, M.R.O.; Abbas, A.; Wang, X.; Mutinda, G. Solar Energy Potential in the Yangtze River Delta Region-A GIS-Based Assessment. Energies 2021, 14, 143. https://doi.org/10.3390/en14010143

Received: 26 November 2020 Accepted: 19 December 2020 Published: 29 December 2020

Publisher's Note: MDPI stays neutral with regard to jurisdictional clai$\mathrm{ms}$ in published maps and institutional affiliations.

Copyright: (C) 2020 by the authors. Licensee MDPI, Basel, Switzerland. This article is an open access article distributed under the terms and conditions of the Creative Commons Attribution (CC BY) license (https:// creativecommons.org/licenses/by/ $4.0 /)$.

\begin{abstract}
Decarbonization of electrical power generation is an essential necessity in the reduction of carbon emissions, mitigating climate change and attaining sustainable development. Solar energy as a substitution for fossil fuel-based energy sources has the potential to aid in realizing this sustainable future. This research performs a geographic information systems (GIS)-based assessment of the solar energy potential in the Yangtze River Delta region (YRDR) of China using high-resolution solar radiation data combined with geographical, social, environmental and cultural constraints data. The solar energy potential is evaluated from the geographical and technical perspective, and the results reveal that the YRDR is endowed with rich solar energy resources, with the geographical potential in the suitable areas ranging from $1446 \mathrm{kWh} / \mathrm{m}^{2}$ to $1658 \mathrm{kWh} / \mathrm{m}^{2}$. It is also estimated that the maximum solar capacity potential could be up to $4140.5 \mathrm{GW}$, illustrating the high potential available for future capacity development in this region. Realizing this significant potential as an alternative for fossil fuel-based electricity generation would result in a substantial mitigation of $\mathrm{CO}_{2}$ emissions in this region, where air pollution is severe. Potential evaluations found that Jiangsu and Anhui provinces provide the most optimal areas for the development of solar photovoltaics (PV) installations, as they have the highest geographical and technological solar energy potential. Further, findings of the case study undertaken at a solar PV plant show disparities between actual generated power and technical solar potential, highlighting the significance of utilizing solar radiation data from local ground-based meteorological stations. This study provides policy makers and potential investors with information on solar energy potential in the Yangtze River Delta region that would contribute to solar power generation development.
\end{abstract}

Keywords: solar energy potential; GIS-based assessment; spatial analysis; Yangtze River Delta region

\section{Introduction}

Air pollution and environmental degradation is set to increase due to continued utilization of fossil fuel-based energy sources for production of electricity [1]. This combined with anthropogenically induced climate change, the associated environmental crisis and the depletion of fossil fuel resources will lead to challenges in electricity supply [2,3]. The decarbonization of electrical power generation is an essential necessity in the reduction of $\mathrm{CO}_{2}$ emissions, mitigating the detrimental impacts of climate change, attaining sustainable development and realizing a sustainable future [4].

Solar energy, particularly solar photovoltaic (PV), can provide a sustainable alternative as it shows the most steady and predictable power supply curves and offers the lowest prices per installed power unit in comparison to other renewable energy sources. In fact, solar energy is the most promising and competitive option among renewable energy 
sources $[5,6]$. One of the key advantages that solar PV has over conventional fossil fuelbased power production is the ten-fold reduction in $\mathrm{CO}_{2}$ emissions from $1000 \mathrm{gCO}_{2} / \mathrm{kWh}$ to $90 \mathrm{gCO}_{2} / \mathrm{kWh}$ [1], which facilitates the critically needed de-carbonization of the global energy supply. Globally, the PV market had a growth rate of 41\% between 2000 and 2015 [2]. Currently, the total cumulative installed PV capacity stands at about $627 \mathrm{GW}$ at the end of 2019 [7]. In terms of total capacity, China has a cumulative PV installed capacity of 204.7 GW, representing 32.6\% of the global PV installed capacity at the end of 2019 [7], surpassing by a huge margin the government's target for 2020 .

In order to successfully exploit solar energy, it is critical to first evaluate the solar energy potential on the ground [5]. This will allow the identification of suitable areas for the development of solar installations. Geographical information systems (GIS) and remote sensing have emerged as the most popular tools for the potential estimation of renewable sources and identification of optimal sites for renewable energy development [5,6,8-11]. Sun et al. [8] adopted a grid cell approach to evaluate the geographical and technical potential of solar PV generation in Fujian Province of China. Sun et al. [9] proposed a GIS-based multiregional analytical framework considering interregional suitability differences and inter-renewable energy source competitiveness for different areas in the eastern coastal regions of China to support spatial planning strategies for renewable energy source utilization. Liu et al. [12] used a gray cumulative prospect theory with GIS for the optimal site selection of PV plants in four cities in northwest China. A GIS-based spatial multicriteria evaluation approach using fuzzy quantifiers was adopted by Charabi et al. [13] to assess the land suitability for large-scale PV farm development in Oman. Doorga et al. [14] used GIS combined with an analytical hierarchy process (AHP); a multi-criteria decisionmaking technique, to identify the spatial suitability for installations of ground-mounted solar farms in Mauritius and Yushchenko et al. [15] applied the same methodology to estimate geographical and technical potentials for solar electricity generation in rural areas of West Africa.

Agrivoltaics is the concept of co-developing the same area of land for both solar PV power as well as for conventional agriculture. It reduces competition for limited land resources by rising food production demand and energy demand, which are exacerbated by the increasing world population [16]. Limited land resources in the Yangtze River Delta region (YRDR) of China are mainly due to accelerated urbanization, industrialization and intensive agriculture. Scarce land resources attributed to intensive agriculture make agrivoltaics an attractive prospect for application in this region, as it would allow largescale exploitation of solar energy without displacing agricultural land usage, mitigating the issue of land competition while enhancing high energy and food production. Marrou et al. $[17,18]$ successfully deployed agrivoltaics in the cultivation of lettuce, cucumber and wheat in Montpellier, France, while Schindele et al. [19] applied agrophotovoltaics in the production of organic potato and winter wheat in Germany. Simulation results of the study on agrivoltaics system potential by Dinesh et al. [16] showed an over 30\% increase in economic value from farms deploying agrivoltaics systems and a $40 \mathrm{GW}$ to $70 \mathrm{GW}$ increase in $\mathrm{PV}$ power on conversion of lettuce cultivation to agrivoltaics systems in the United States. Barron-Gafford et al. [20] observed that agrivoltaics lead to increased power production, greater food production due to reduced plant drought stress and the plants helped to reduced PV panel heat stress. Dual land usage could alleviate land competition, creating a significant potential for future energy sustainability. Adeh et al. [21] noted that the global energy demand of 21 PWh could be met by solar energy if less than $1 \%$ of agricultural land was converted to agrivoltaics systems.

To develop the solar PV generation in the YRDR, it is crucial to perform a complete solar energy potential analysis. Indeed, such a detailed analysis would provide policy makers and potential investors with information that would contribute to solar power generation development.

Therefore, the objective of this study is to perform a comprehensive assessment of the solar energy potential in the Yangtze River Delta region using high-resolution solar 
radiation data and the best available geographical, social, environmental and cultural constraints data.

Further, as a case study, the methodology adopted was utilized to obtain the technical potential solar energy of the land area of a solar PV plant in Baima, Nanjing which employs the concepts of agrivoltaics and floatovoltaics. Thereafter, a comparative analysis of the actual generated power of the solar power plant and the technical solar energy potential was undertaken.

\section{Study Area}

The target region of this research is the Yangtze River Delta region (YRDR) which encompasses Jiangsu, Zhejiang and Anhui provinces and Shanghai municipality [22] in the eastern region of China, geographically located between longitude $115^{\circ} \mathrm{E}$ and $122^{\circ} \mathrm{E}$ and latitude $27^{\circ} \mathrm{N}$ and $35^{\circ} \mathrm{N}$. The YRDR has a total land area of $346,814 \mathrm{~km}^{2}$ accounting for $3.69 \%$ of total Chinese land area with a total population of 163.3 million people and which generated $20 \%$ of China's total GDP in 2018 [23]. The YRDR is located within the sub-tropical monsoon climate and according to the Chinese meteorological administration (CMA), an average global horizontal irradiance (GHI) of about $5.8 \mathrm{kWh} / \mathrm{m}^{2} /$ day is incident on the YRDR during the summer months and $2.5 \mathrm{kWh} / \mathrm{m}^{2} /$ day during the winter months. Annual energy consumption was about 1445.3 TWh in 2018, mainly on the account of the industrial sector, with most of the energy derived from fossil fuel-based energy sources. The YRDR is an importer of electricity with about $50 \%$ of the energy imported from other regions, which poses a threat to this region's economic development and energy security.

The provincial administrative boundaries of China illustrating the YRDR as well as the provincial administrative boundaries of the YRDR are as shown in Figure 1.

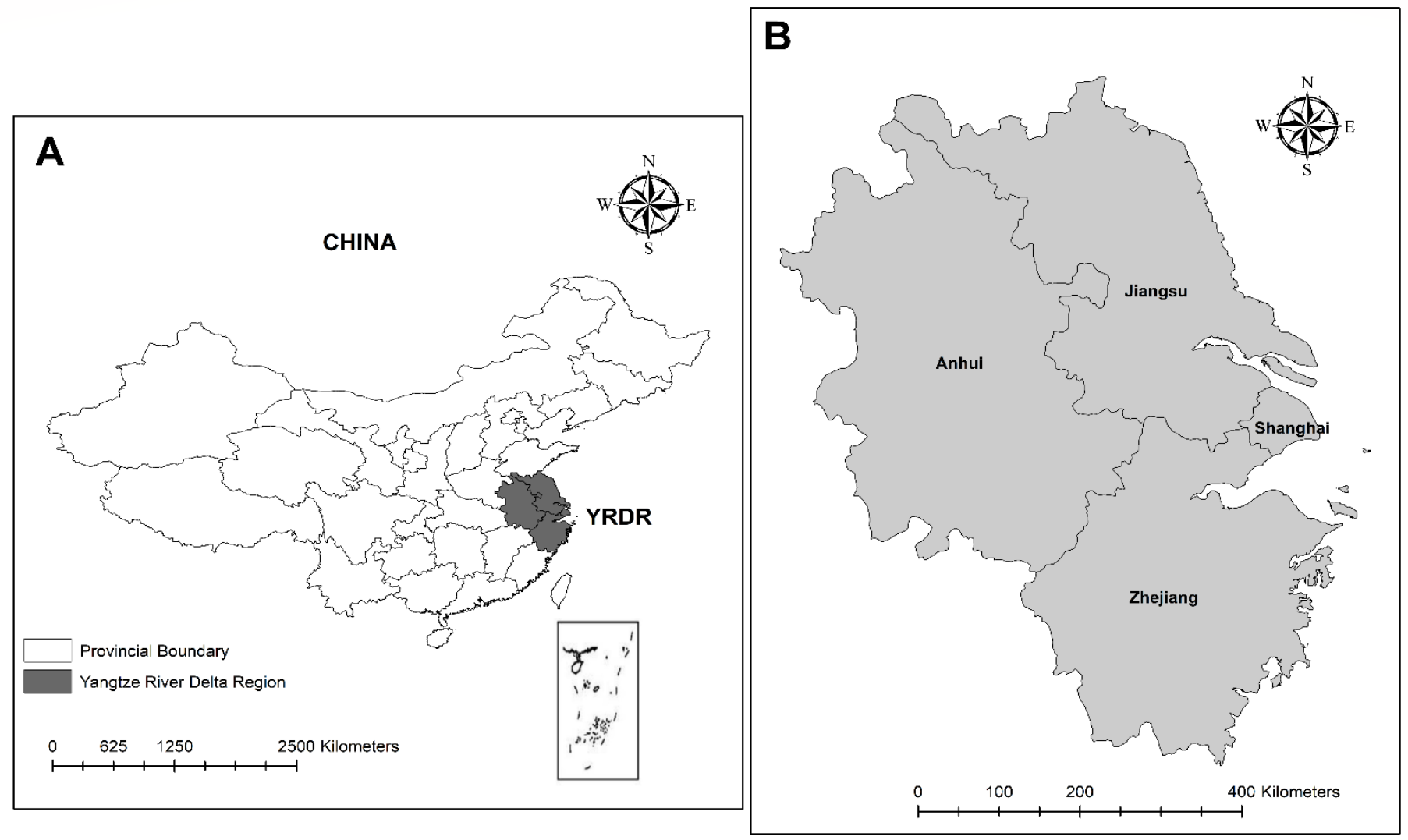

Figure 1. The provincial administrative boundaries of: (A) China and (B) Yangtze River Delta region. 


\section{Methodology}

The evaluation of solar energy potential is dependent on land cover, local spatial and temporal solar energy resources, economics of solar energy products, available solar power technologies and governmental policies [8]. In light of these factors, a solar energy potential analysis methodology is formulated. Initially, the solar radiation in the YRDR is mapped to determine its spatial and temporal characteristics. Thereafter, a multi-criteria approach is utilized to determine suitable land areas based on geographical, social, environmental and cultural constraints. Finally, the geographical potential and technical potential of solar energy are assessed in the YRDR. The geospatial processes and analysis were performed on a GIS platform: Environmental Systems Research Institute (Esri) software ArcGIS Version 10.8.0.

The large-scale application of solar energy can be taken as a primary measure to address the current and future energy challenges in the YRDR and simultaneously reduce carbon emissions. Therefore, in this study, a combination of ground-mounted PV installations and agrivoltaics systems is adopted. Agrivoltaics leverage the superposition of food and energy production for mutual benefit [21]. The configuration adopted for the deployment of agrivoltaics is the stilt-mounted PV modules. With the limited land resources, this configuration offers efficient land usage as it provides space underneath the PV modules and stilts for agriculture. The stilts' clearance height and the length and width of the space between adjacent stilts are adequate enough for standard farming machinery and industrial-scale harvesters to operate without any hinderance while maintaining a safe distance from the PV modules. This agrivoltaics configuration has been successfully implemented in France [17,18], Germany [19], Japan [24], USA, Italy, Malaysia and Chile.

\subsection{Solar Potential Evaluation}

The solar energy potential can be grouped into two categories: geographical potential and technical potential [10]. Geographical potential is defined as the amount of the total annual solar radiation available in a given area, factoring in existing geographical, social, environmental and cultural constraints. The technical potential of a given area is defined as the amount of geographical potential in that area that can actually be translated into electricity, taking into account the solar power technologies employed [10].

\subsubsection{Geographical Potential}

Social, economic, environmental and cultural constraints were applied to identify suitable locations for solar PV development to avoid biodiversity loss, help in preserving the ecosystem, protect world heritage sites and mitigate against habitat destruction. These unsuitable locations were excluded from the land area. The geographical potential is thereafter determined by averaging the solar radiation intensity in the suitable areas.

The exclusion criteria and constraint analysis undertaken were based on insights from relevant literature and are detailed as follows:

1. Land use and land cover (LULC)

GlobCover 2009 land cover data derived from the European Space Agency (ESA) are utilized to exclude areas of unsuitable land types for PV installations. The land cover data used the UN land cover classification to define 22 global land cover classes with a resolution of $300 \mathrm{~m}$ and an accuracy of $73 \%$ weighted by class area. As recommended by Jain et al. [25] and Phadke et al. [26], suitable land areas for solar PV were land areas with values of 20,130,140,150 and 200. The details of the land area values are as described in Table 1. In addition, land areas with a value of 11 were also integrated with the deployment of agrivoltaics systems in areas with cropland. It is noteworthy that the power plant used as a case study in this article is located within land area with a value of 11 . The other 13 land types are excluded to obtain the suitable land area. 
Table 1. GlobCover land use land cover.

\begin{tabular}{|c|c|}
\hline Value & GlobCover Legend \\
\hline 11 & Irrigated croplands (or aquatic) \\
\hline 14 & Rainfed croplands \\
\hline 20 & Mosaic cropland (50-70\%)/vegetation (grassland/shrubland/forest) $(20-50 \%)$ \\
\hline 30 & Mosaic vegetation (grassland/shrubland/forest) $(50-70 \%) /$ cropland $(20-50 \%)$ \\
\hline 40 & Closed to open $(>15 \%)$ broadleaved evergreen or semi-deciduous forest $(>5 \mathrm{~m})$ \\
\hline 50 & Closed $(>40 \%)$ broadleaved deciduous forest $(>5 \mathrm{~m})$ \\
\hline 70 & Closed ( $>40 \%$ ) needle-leaved evergreen forest $(>5 \mathrm{~m})$ \\
\hline 100 & Closed to open $(>15 \%)$ mixed broadleaved and needle-leaved forest $(>5 \mathrm{~m})$ \\
\hline 110 & Mosaic forest or shrubland (50-70\%)/grassland (20-50\%) \\
\hline 120 & Mosaic grassland $(50-70 \%) /$ forest or shrubland $(20-50 \%)$ \\
\hline 130 & $\begin{array}{l}\text { Closed to open }(>15 \%) \text { (broadleaved or needle-leaved, evergreen or deciduous) } \\
\text { shrubland }(<5 \mathrm{~m})\end{array}$ \\
\hline 140 & Closed to open ( $>15 \%$ ) herbaceous vegetation (grassland, savannas or lichens/mosses) \\
\hline 150 & Sparse $(<15 \%)$ vegetation \\
\hline 170 & $\begin{array}{l}\text { Closed }(>40 \%) \text { broadleaved forest or shrubland permanently flooded-saline or } \\
\text { brackish water }\end{array}$ \\
\hline 180 & $\begin{array}{l}\text { Closed to open }(>15 \%) \text { grassland or woody vegetation on regularly flooded or } \\
\text { waterlogged soil-fresh, brackish or saline water }\end{array}$ \\
\hline 190 & Artificial surfaces and associated areas (urban areas $>50 \%$ ) \\
\hline 200 & Bare areas \\
\hline 210 & Water bodies \\
\hline 220 & Permanent snow and ice \\
\hline
\end{tabular}

2. Geographical restriction

The land slope has an influence on the inclination and orientation of solar PV panels, and steep land increases the cost of installation and maintenance of solar PV developments. There is no consensus on the maximum acceptable slope, as there is no exact number at which a slope is considered to be unfeasible for the construction of solar PV installations, with studies adopting a surface slope of between $3^{\circ}$ to $5^{\circ}[13,27]$. Therefore, a cut-off of $5^{\circ}$ was selected, which was in accordance with the regulations of China's National Ministry of Land and Resources [28], and land areas with a slope above this cut-off value were considered unsuitable and excluded. The required land surface slope was extracted from the YRDR digital elevation model (DEM) using GIS spatial tools.

3. Water bodies

Water bodies such as rivers, lakes, reservoirs, dams and wetlands were excluded from suitable areas and a buffer of $300 \mathrm{~m}$ was imposed.

4. Built-up area

Urban and major settlements areas with dense populations were excluded due to regulations restricting the deployment of utility-scale solar PV installations in these areas. 5. Rail and road networks

Rail and road networks are deemed to be unsuitable for development and were excluded with a buffer of $300 \mathrm{~m}$ imposed. Airports and other land surface transport infrastructure were also excluded.

6. Protected areas

Protected areas included: nature reserves, land marks, national parks, fish and wildlife areas, sanctuaries, threatened vegetation, religious and touristic sites. In order to preserve these invaluable treasures for the future generations, protected areas were also excluded and considered unsuitable.

The land use land cover and topographical GIS datasets used in this study are as presented in Table 2. 
Table 2. Topographical and land cover datasets used to evaluate suitable land areas.

\begin{tabular}{cc}
\hline Theme & Dataset \\
\hline Digital elevation model (DEM) & NASA SRTM 90 m, version 4 [29] \\
Administrative boundary & GADM, version 3.6 [30] \\
Water bodies & WWF [31] \\
Protected areas & WDPA [32] \\
Urban built-up areas & Natural Earth [33] \\
Road and Rail networks & DIVA-GIS [34] \\
Land use land cover & GlobCover [35] \\
\hline SRTM: Shuttle Radar Topography Mission, WWF: World Wide Fund, WDPA: World Database on Protected Areas.
\end{tabular}

\subsubsection{Technical Potential}

Solar photovoltaics is based on semiconductor technology that converts sunlight into electricity. According to Lacerda et al. [36] and Tyagi et al. [37], photovoltaic technologies are generally classified into the following groups depending on the raw material utilized:

- Photovoltaic cells that use the technology of crystalline silicon: monocrystalline silicon and in the multicrystalline form: polycrystalline silicon

- Thin film cells which are generally grouped into: amorphous silicon, cadmium telluride, copper indium selenide and copper and indium-gallium dieseline.

- Organic solar cells

- Dye-sensitized solar cells

- Compounds III-V solar cells in which nanotechnology is applied in the development of the solar cells

- Crystal silicon solar cells are predominant in the PV market with the market share of monocrystalline solar cells at about $80 \%$ [37].

Technical potential is the amount of geographical potential that can be translated into electricity considering the available solar power technologies and, as such, the evacuated energy levels depend on three main factors: panel efficiency, area factor and performance ratio of the PV system. Panel efficiency is by extension the efficiency of solar cells used in the manufacture of the PV module. The efficiency improvement of solar cells has attracted the attention of many researchers and extensive research has been carried out to that end. Currently, the efficiency of monocrystalline silicon-based PV cells can reach as high as $28 \%$ [38], however, for the majority of commercially available monocrystalline cells, the efficiency generally lies between $15 \%$ and $17 \%$ [37] with the efficiency of polycrystalline solar cells reaching $19.8 \%$ [3]. Therefore, in this study, modules from single crystal photovoltaic cells with an efficiency of $16 \%$ are utilized and the PV system is assumed to be a fixed mounted system.

The area factor is the fraction of the exploitable land area that can be covered with solar panels, leaving space between the solar panel array rows to minimize shading and accommodate service roads. An area factor of $70 \%$ was selected as it offered the optimal value to prevent the shadow effect [13]. This area factor value has been adopted by other studies that employed a similar methodological approach and the geographical locations correspond to the study area in this research $[11,39]$. The performance ratio of the complete PV system as defined in International Standard of the International Electrotechnical Commission (IEC) 61724 characterizes the total impact of losses on the PV array's rated output as a result of system component inefficiencies or failures, array temperature and incomplete utilization of solar irradiation, and it ranges from $70 \%$ to $85 \%$. Based on the reviewed literature [15,40-43], a value of $85 \%$ was adopted. This is also in agreement with the 2020 US Department of Energy (DOE) —National Renewable Energy Laboratory (NREL) recommended value of $86 \%$ [44]. 
The technical potential of the suitable land areas was computed using Equation (1), which is a modified form of the relationship proposed by Charabi et al. [13], integrating the performance ratio of the PV system, as was undertaken by Yushchenko et al. [15]:

$$
G P=S R \times C A \times A F \times \eta \times P R
$$

where GP is the technical solar potential; the electric power generation potential, $S R$ is the solar radiation received per unit horizontal area, $C A$ the calculated total area of suitable land, $A F$ is the area factor, $\eta$ the efficiency of the monocrystalline photovoltaic cells and $P R$ is the assumed performance ratio of the PV system.

\subsubsection{Solar Radiation Data}

Clifton et al. [45] adopted solar datasets from the National Aeronautics and Space Administration (NASA) Surface Meteorology and Solar Energy (SSE) program database to assess concentrated solar power (CSP) potential in the wheatbelt region of rural Western Australia and found that the NASA SSE data produced overestimates, therefore, the authors integrated data from the local ground-based meteorological station with the satellite datasets to achieve a fitting correction. Furthermore, NASA SSE satellite GHI datasets tend to be low resolution and utilizing coarse spatial resolution datasets could result in the under- or overestimation of potential estimates, as was noted by Jain et al. [25]. Thus, solar radiation data used in this study were obtained from WorldClim [46]. WorldClim provides a dataset of spatially interpolated, monthly average GHI for global land areas at a high spatial resolution of $1 \mathrm{~km}^{2}$. The monthly GHI data are aggregated across a temporal range of 1970-2000, utilizing data values from between 9000 and 60,000 weather stations, making WorldClim a reliable data source. In consistence with the study of Yang et al. [10], the GHI values for each month are multiplied by the number of days in that month and an estimate of the annual GHI is obtained by summing up all of the monthly GHI values.

\section{Results and Discussion}

\subsection{Land Suitability}

The GlobCover LULC of the YRDR is shown in Figure 2A and the excluded LULC areas are as presented in Figure 2B. The excluded areas include urban areas, rainfed croplands, dense grasslands, dense shrublands, thick forests and water bodies which are unsuitable for PV plant development. This is due to the fact that grasslands, shrublands, forests and water bodies are critical ecological elements that need to be preserved to avoid biodiversity loss and maintain the ecosystem, and would be damaged by the construction of PV installations. As illustrated in Figure $3 \mathrm{~A}$, areas with land surface slopes greater than $5^{\circ}$ are excluded as steep slopes would complicate PV systems installation, and increase construction and maintenance costs. Figure $3 \mathrm{~B}$ shows protected areas that are excluded as unsuitable as there is a need to preserve these protected areas for the future generations. Railroad networks are also illustrated and are excluded as it is impractical to setup PV installations on transport infrastructure. Upon meeting all environmental, economic, social and cultural criteria, the sum of the suitable land area was calculated to be $149,120 \mathrm{~km}^{2}$ accounting for $43 \%$ of the total YRDR land area. The suitable land area map illustrating the spatial distribution of the exploitable land areas is presented in Figure 4. 

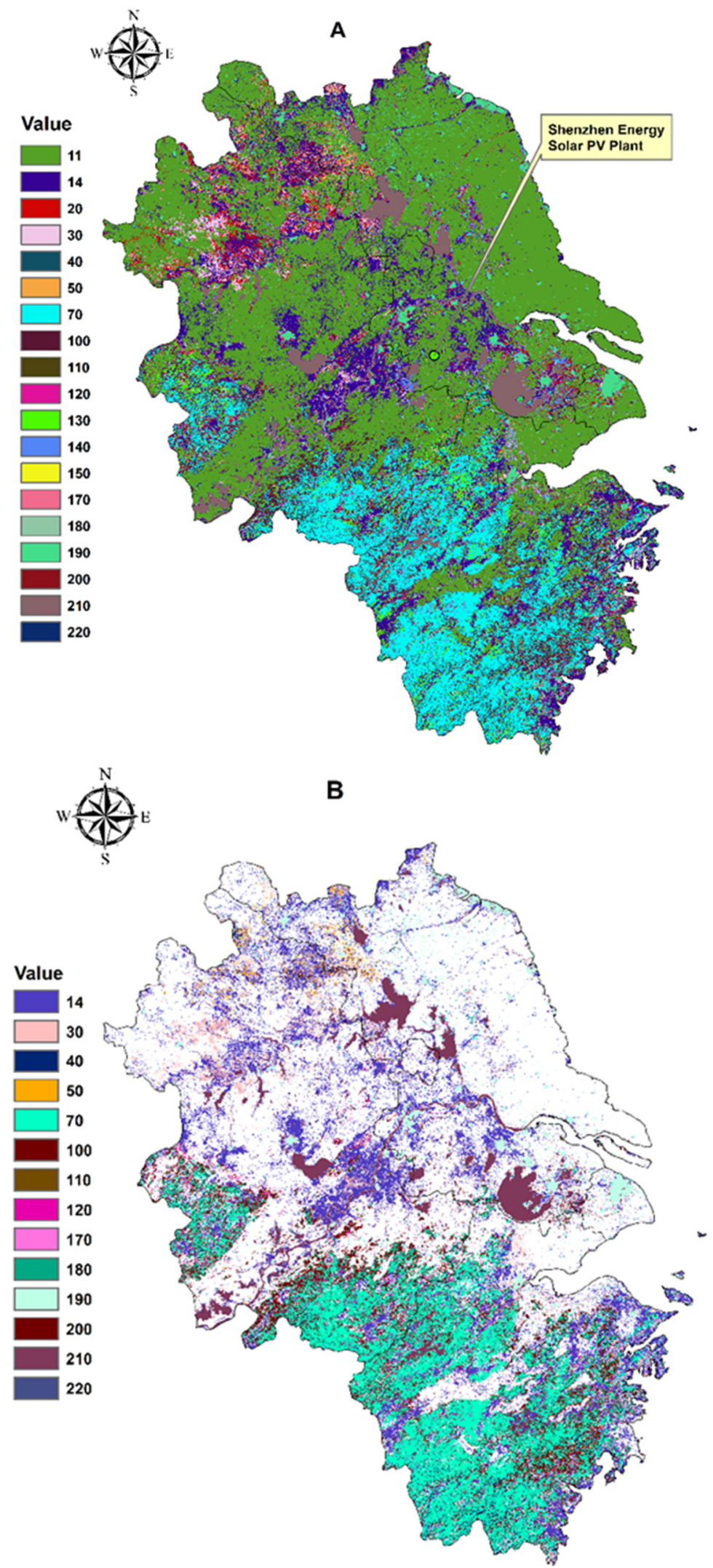

Figure 2. Yangtze River Delta region (YRDR): (A) land use land cover; (B) excluded land use land cover. 

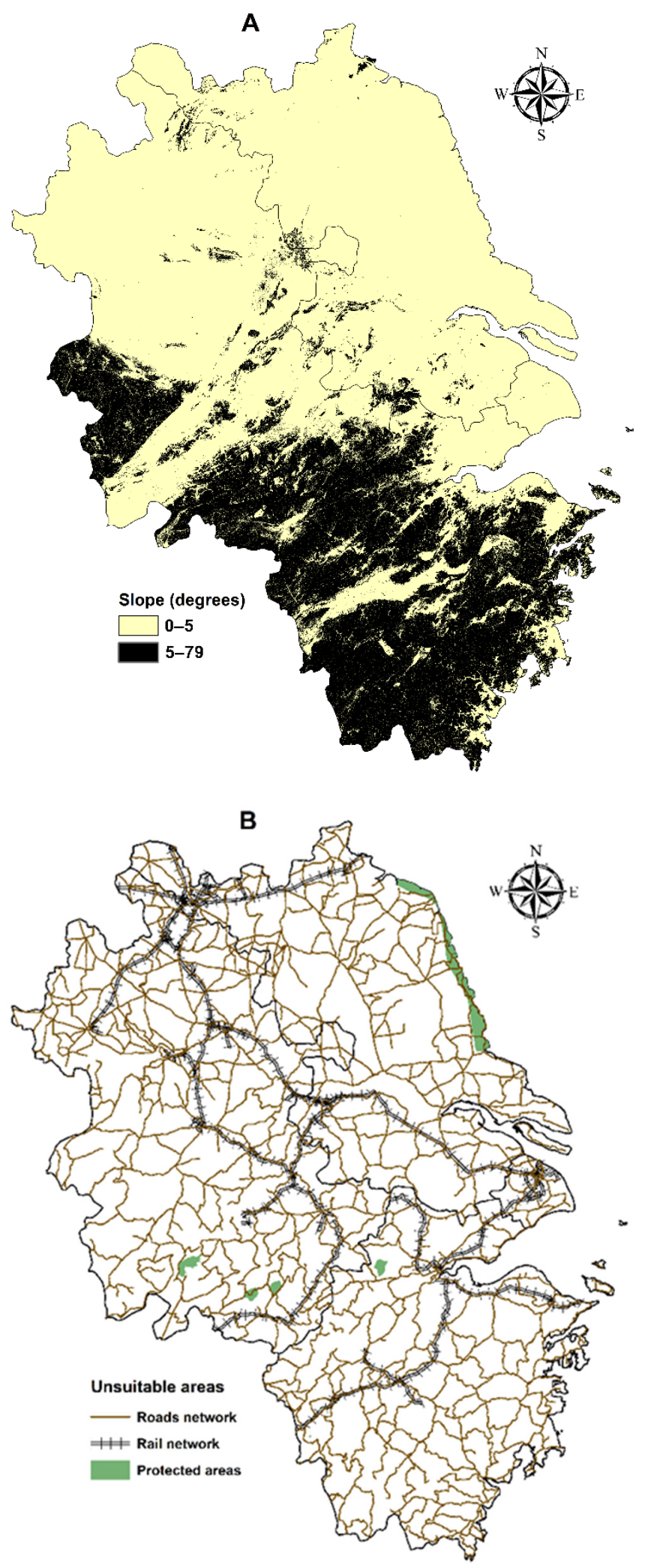

Figure 3. Yangtze River Delta Region: (A) reclassified slope and (B) road, rail network and protected areas 


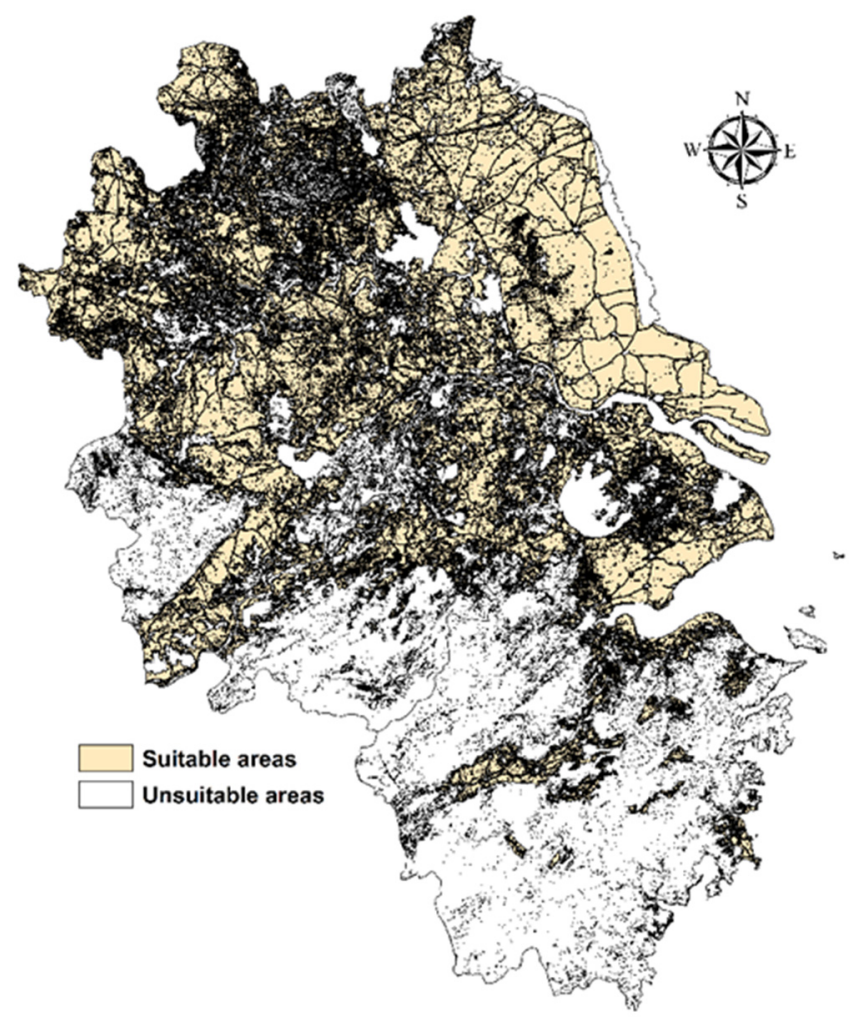

Figure 4. YRDR suitable and unsuitable areas.

Suitable land areas are summarized at the administrative division scale, as shown in Table 3.

Table 3. Suitable areas in each administrative division in the Yangtze River Delta region (YRDR).

\begin{tabular}{ccccc}
\hline $\begin{array}{c}\text { Administrative } \\
\text { Division }\end{array}$ & Suitable Area $\left(\mathbf{k m}^{\mathbf{2}}\right)$ & $\mathbf{1}$ Total Land Area $\left.\mathbf{( k m}^{\mathbf{2}}\right)$ & $\begin{array}{c}\text { Proportion of Suitable } \\
\text { Area to the Total } \\
\text { Suitable Area (\%) }\end{array}$ & $\begin{array}{c}\text { Proportion of Suitable Area } \\
\text { to Total Land Area (\%) }\end{array}$ \\
\hline Anhui & $64,370.97$ & $140,627.14$ & 43.17 & 45.77 \\
Jiangsu & $65,330.24$ & $99,965.79$ & 43.81 & 65.35 \\
Shanghai & 3965.75 & 5943.96 & 2.66 & 66.71 \\
Zhejiang & $15,450.49$ & $100,277.12$ & 10.36 & 15.41 \\
Total area & $149,117.45$ & $346,814.01$ & - & - \\
\hline
\end{tabular}

${ }^{1}$ Total land area: this is the total land area of each administrative division.

It is evident from Table 3 that Shanghai, Jiangsu and Anhui have the highest proportion of suitable land to their provincial total land area, accounting for $66.71 \%, 65.35 \%$ and $45.77 \%$, respectively, mainly due to low slope, as most of the land area in these regions is flat. In contrast, Zhejiang has low availability of suitable land in proportion to its total provincial total land area, at just $15.41 \%$, primarily because of land morphology restrictions, with slopes above the cut-off value being prevalent in this region. The fraction of exploitable land areas in Jiangsu, Anhui, Zhejiang and Shanghai relative to the total suitable land area in the YRDR is $43.81 \%, 43.17 \%, 10.36 \%$ and $2.66 \%$, respectively. The largest exploitable land availability is in Jiangsu, followed closely by Anhui. The low proportion of exploitable land in Shanghai is mainly due to its relatively small total land area, at only $5943.96 \mathrm{~km}^{2}$, coupled with its large urbanized area.

The YRDR encompasses regions with accelerated economic growth and flourishing industries, and as such, development of utility-scale PV installations cannot be isolated from these aspects that usually result in rapid urbanization. The flourishing economy and industries will definitely continue to result in urban growth and the construction of PV 
installations should be aligned with the government urbanization policies. This will allow for sufficient land area to accommodate the accelerated urban expansion, including other ecological efforts such as afforestation.

\subsection{Geographical Solar Potential}

The spatial variation of annual GHI incident on the suitable land areas in the YRDR is shown in Figure 5.

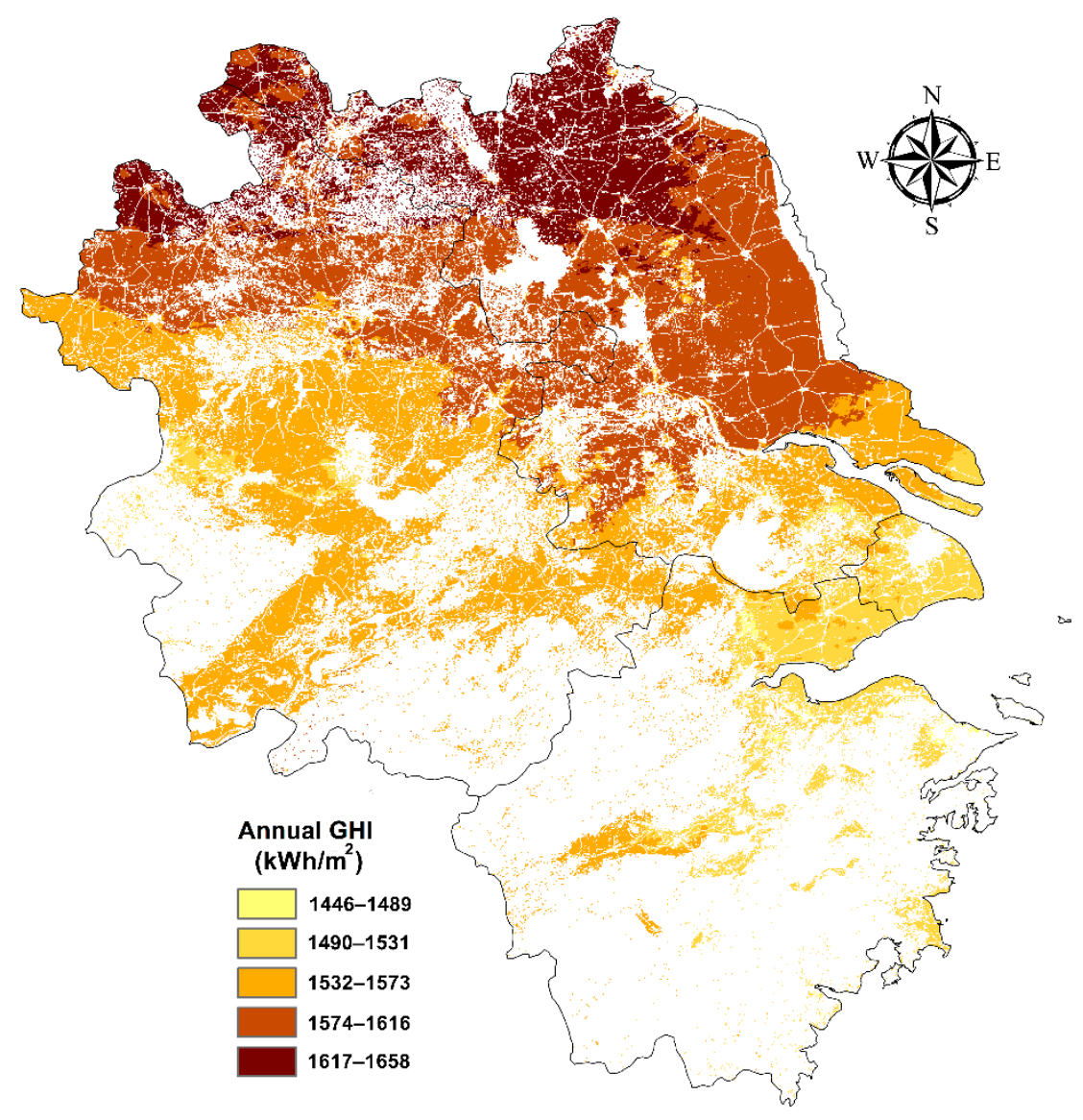

Figure 5. YRDR geographical solar energy potential.

Figure 5 categorizes the exploitable land areas according to annual GHI, with estimations showing values ranging from $1446 \mathrm{kWh} / \mathrm{m}^{2}$ to $1658 \mathrm{kWh} / \mathrm{m}^{2}$, showing that the YRDR is endowed with rich solar resources that are feasible for PV installation. A minimum annual GHI of $1000 \mathrm{kWh} / \mathrm{m}^{2}$ was used in the solar energy potential estimation study undertaken by IRENA [47] in rural areas of the Economic Community of West African States Region (ECOWAS) and Anwarzai et al. [48] utilized a threshold minimum annual GHI value of $1278 \mathrm{kWh} / \mathrm{m}^{2}$ for potential assessment in Afghanistan. Generally, annual GHI values higher than $1400 \mathrm{kWh} / \mathrm{m}^{2}$ have been extensively adopted in studies as a threshold for feasible PV development.

\subsection{Technical Solar Potential}

Employing a land use factor of 8.9 acres/MW, as was recommended by Ong et al. [49], the maximum solar capacity potential in the YRDR can be up to $4140.5 \mathrm{GW}$, which is equivalent to 98.85 times the total cumulative installed capacity in the YRDR at the end of 2019. In order to show the potential for further PV development, the ratio of potential to installed PV capacity at the administrative division level was assessed and is presented in Figure 6. Installed solar capacity data for 2019 are obtained from the China Electricity Council (CEC) [50]. 


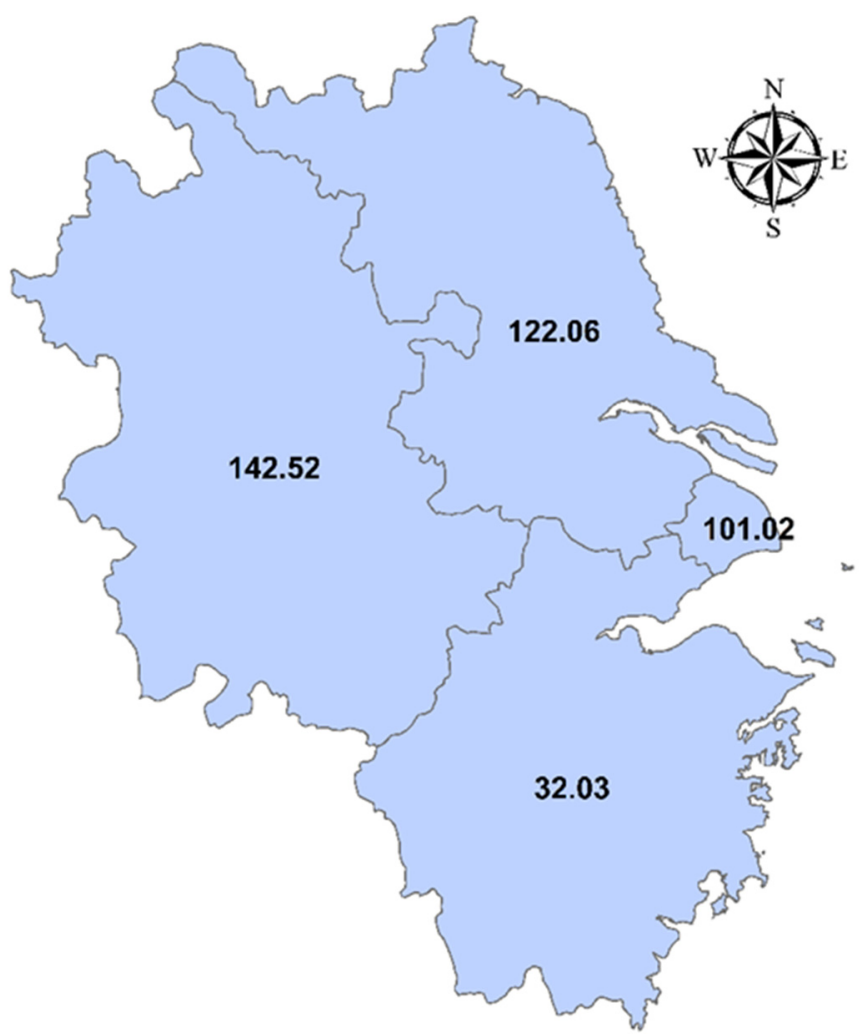

Figure 6. Ratio of potential solar capacity to total installed solar capacity in 2019.

As can be seen in Figure 6, Anhui has the highest potential for further development largely because it has the lowest installed capacity, upon exclusion of Shanghai, at $12.54 \mathrm{GW}$ and the second largest capacity potential in the YRDR. Jiangsu also has a high potential for future development, with a ratio of 122.06, despite the fact that it has the largest installed capacity at $14.86 \mathrm{GW}$. This is attributed to the fact that it has the highest capacity potential in the YRDR. Despite having the lowest capacity potential, Shanghai has ratio of 101.02 mainly because it has the lowest installed capacity in the YRDR at $1.09 \mathrm{GW}$. This highlights the available potential for future development in this region, but this may not be fully realized due to the rapid urbanization in this region that would lead to limited exploitable areas. Zhejiang records the lowest degree for future development, with a ratio of just 32.03 , due to the fact that it has one of the largest installed capacities at $13.39 \mathrm{GW}$ but has the lowest potential capacity; this is a result of scarce suitable areas stemming from land morphology limitations.

The estimated annual technical potential of the suitable land areas in the YRDR is estimated to be 7550 TWh which represents 5.22 times the total electricity consumption in the YRDR in 2018. These results depict the significant solar energy potential available which can meet the YRDR power needs and turn the YRDR into an exporter of electricity if the potential is realized. Achieving this potential as a replacement for fossil fuel-based electricity generation would result in a significant reduction of $\mathrm{CO}_{2}$ emissions. This reduction in greenhouse gas (GHG) emissions would be in accordance with two government action plans [51,52] to cut air pollution in the Beijing, Tianjin and Hebei region, YRDR and Pearl River Delta area, where air pollution is severe, and China's emission reduction commitment in the 2015 Paris Agreement [4].

To highlight the potential distribution, the technical potential is evaluated together with the 2018 electricity consumption at the administrative division level and illustrated in Figure 7. Annual electricity consumption data for 2018 are obtained from the China Statistical Yearbook 2019 [53]. 


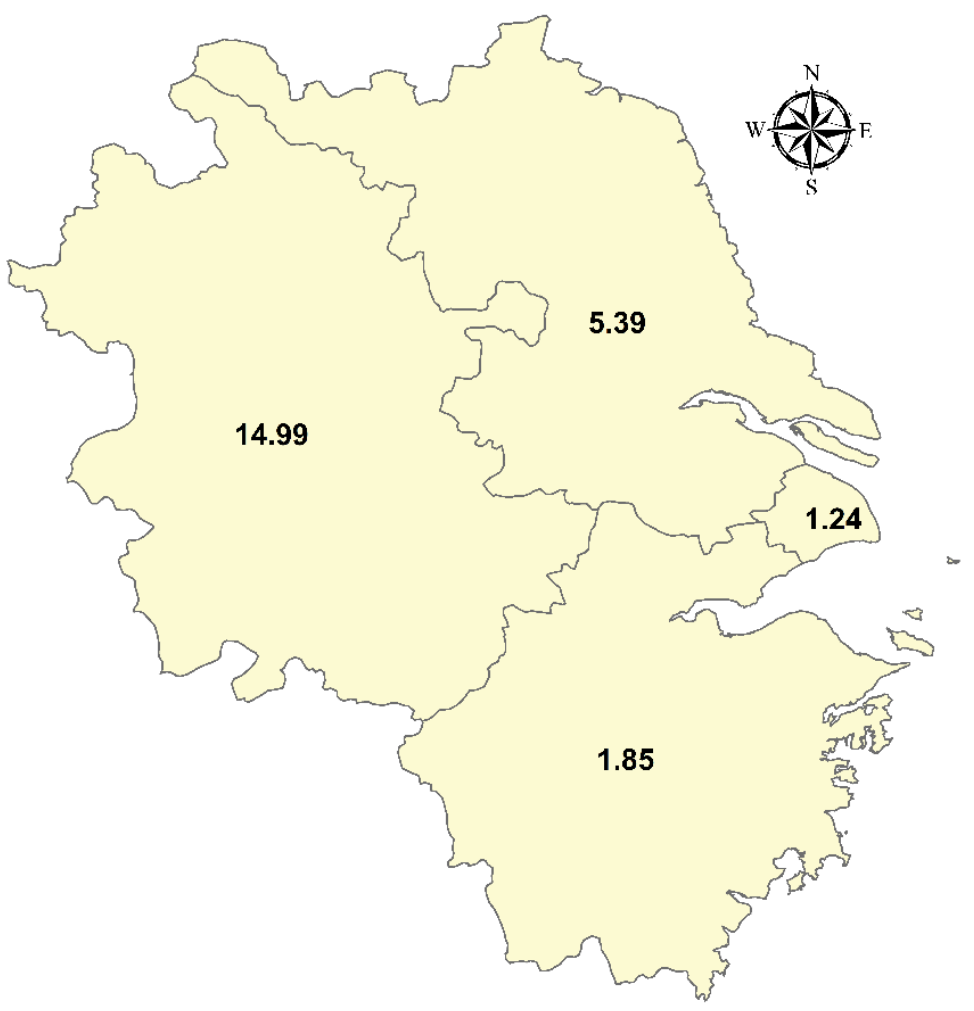

Figure 7. Ratio of technical energy potential and 2018 electricity consumption.

There is a variation in the technical potential at the administrative division level, with Jiangsu and Anhui having the highest potential, primarily because of a higher proportion of exploitable areas, as the technical potential is significantly determined by the suitable land area. Conversely, Zhejiang and Shanghai have significantly lower technical potential due to the fact that they have a lower proportion of suitable land areas. As seen in Figure 7 Jiangsu registered a low ratio of 5.39 primarily because it recorded the highest electricity consumption. Zhejiang closely followed Jiangsu with high electricity consumption but recorded a ratio of just 1.84, as it has a low potential stemming from the fact that it has a low percentage of suitable area. Anhui had a relatively lower electricity consumption in comparison to Jiangsu and Zhejiang, but it has the second highest technical potential in the YRDR, which resulted in the highest ratio at 14.99. The ratio of technical potential to electricity consumption for Shanghai is the lowest at 1.24, largely because it has scarce exploitable land area but has a large electricity consumption.

The potential solar capacity and annual technical potential obtained of $4140.5 \mathrm{GW}$ and 7550 TWh is about 20.29 times and 25.17 times higher, respectively, than estimates by He et al. [54], who assessed solar energy potential in China at the provincial level. The assessment included evaluations for different solar power technologies and the estimates for solar PV yielded a solar capacity potential and a technical solar potential of about 204 GW and 300 TWh, respectively, in the YRDR. This disparity is mainly on account of different land selection criteria on slopes and croplands, as the estimated potentials are directly correlated to the exploitable land areas. The authors utilized a slope cut-off of 3\% as compared to $5 \%$ used in this study and excluded irrigated croplands, which were the basis of agrivoltaics systems in this research. This disproportion in the potential solar capacity and annual technical potential further underscores the potential of leveraging agrivoltaics systems in the achievement of a sustainable energy future, corroborating conclusions by Adeh et al. [21].

In summary, Jiangsu and Anhui have the greatest potential for solar energy development as they have the highest geographical and technological solar potential, making them the most optimal for the construction of utility-scale solar PV installations. In contrast, 
Zhejiang and Shanghai have relatively lower geographical potential which, coupled with the smaller exploitable land areas, results in a significantly reduced technological solar energy potential. The YRDR has adequate solar energy generation potential to meet its power demand by aggressively developing solar installations as an alternative for current conventional fossil fuel-based electricity generation. The technical potential exceeding the power needs and the associated substantial mitigation of $\mathrm{CO}_{2}$ emissions highlight the significant economic and environmental benefits that the YRDR can derive from PV electricity.

Dispatchability is the last link in the energy chain. The YRDR encompasses one of the most developed regions of China, with a well-developed grid network. Integration with the national grid would facilitate the dispatch and transmission of power, and eliminate the need for energy storage systems whose cost contributes approximately $50 \%$ of offgrid PV power installations. Moreover, proximity and access to an existing power grid and transmission system can substantially reduce the capital cost of PV installation and minimize transmission power loss.

The YRDR also has an advanced road and rail network, and proximity to road and rail networks would reduce the development costs of PV installations by eliminating the additional cost of transport infrastructure development and the associated environmental damage. Inadequate transportation networks impose a restriction on PV development and its subsequent maintenance.

The maintenance of PV installations is crucial for efficient operation and to enhance the achievement of maximum power generation. The YRDR has abundant water resources which are significant as they would provide the required water resources needed to clean the PV modules. Large quantities of anthropogenic particulate pollutants [55] and dust [56], usually soil, adhere to the PV modules, diminishing the transmittance of the transparent collectors on the PV module surface, resulting in a reduction in solar power generation output [55,56]. In fact, Li et al. [57] investigated the reduction of solar resources to solar photovoltaics due to severe air pollution in China. Therefore, it is essential to regularly clean PV modules to be able to achieve the maximum solar power generation output, as was concluded by Mani et al. [58]. Indeed, Huang et al. [59] considered the areas with a higher water resources availability as having a high weighted priority to develop large-scale PV power stations because poor water resources impose a constraint on the construction of PV installations. On the contrary, some studies argue that the employment of dry-cleaning techniques would allow for efficient water usage and propose alternative self-cleaning methods that use electrostatic, chemical, robotic cleaning technologies and dust accumulation mitigation strategies. However, with no large-scale application, the technical and economic feasibility of these technologies is yet to be determined [60].

One of the challenges that the implementation of this significant solar energy potential will face is the environmental impact of the PV installations. These environmental impacts include and are not limited to habitat fragmentation, obstruction of wildlife passage, biodiversity damage, human health and social wellbeing, air quality, water resource pollution and the alteration of the bio-physical properties of land cover [61]. Therefore, a holistic life cycle assessment (LCA) is recommended and the life cycle impact assessment (LCIA) would provide an understanding of the impact scale of the PV installation on the environment. Besides the LCA, active environmental monitoring is also suggested to provide invaluable data on the influence of operational utility-scale PV installations on the ecosystem, which can give insight and guidance for future installations. Nevertheless, introducing proper policies and regulations can minimize and mitigate against these negative impacts.

The deployment of agrivoltaics has its drawbacks, and these include: (1) increased construction outlay from higher racking costs due to a high mounting height, (2) higher maintenance costs and (3) intermittent shade cast by the PV modules could affect crop yield output. Grains and vegetables are the main crops cultivated in the YRDR. Researchers have successfully cultivated lettuce [18], biogas maize [62], aloe vera [63], pasture grass [64] and tomatoes [65] in experimental agrivoltaics systems. Wheat, peanut, yam, cassava, sweet potatoes, broccoli and cabbage have also been evaluated for agrivoltaics applications [16]. 
These studies concluded that the shading effect does not necessarily diminish agricultural yield output, as was also noted by Marrou et al. [17], who found that some varieties of lettuce produced basically the same yield under the shading effect of the PV modules and under full sunlight. Nonetheless, the intermittent shade cast can be eliminated by utilizing semi-transparent PV modules [66].

Despite these drawbacks, agrivoltaics systems also present benefits that include: (1) increased output generation in comparison to conventional PV installations due to the fact that crops in agrivoltaics improve the temperature of the PV module and reduce panel heat stress, as was observed by Barron-Gafford et al. [20]. PV module output is dependent on the operating temperature of a PV module; this is correlated to the air temperature, wind speed, solar insolation and relative humidity [67]. (2) The shading effect of PV modules can be beneficial to crops. Marrou et al. [17] observed that under the shading effect, certain lettuce varieties produced greater yields in comparison to those under the open sky. In addition, Marrou et al. [68] found that shading resulted in a $14 \%$ to $29 \%$ water saving depending on the degree of shade. This was mainly attributed to the fact that the shading reduced water evaporation during summer and dry periods. This reduction in moisture evaporation has also been seen to mitigate against soil erosion [16]. Temperature-sensitive crops could also be protected from excessive heat by the shading effect, particularly during the summer periods. (3) The PV modules can be instrumental in efficient water usage by draining off water used to clean the modules directly onto the crops, which can be particularly important during dry seasons [16].

\section{Case Study: Shenzhen Energy Solar PV Power Plant}

The Shenzhen Energy solar PV power plant provides a framework for the exploitation of historically unsuitable land areas that are usually considered as constraints to PV development. The constraints in this case are croplands and wetlands. An agrivoltaics system was deployed in the croplands and floating PV was employed on a swamp. Presently, although dams and reservoirs are generally not considered as exploitable areas, advancements in floatovoltaics technology could allow for the exploitation of water surfaces. The potential of floating PV was investigated by the National Renewable Energy Laboratory (NREL) that estimated that installing floatovoltaics on the more than 24,000 man-made US reservoirs had the possibility to generate about $10 \%$ of the US annual electricity production [69]. Water-food-energy nexus synergies [70] and efficient water surface usage [71] are some of the areas of interest that have attracted the deployment of floating PV.

The PV plant is located in Baima, Lishui District, Nanjing, Jiangsu Province, China $\left(31^{\circ} 37^{\prime} 22^{\prime \prime} \mathrm{N}, 119^{\circ} 10^{\prime} 39^{\prime \prime} \mathrm{E}\right)$, as shown in Figure 2A. The ground-mounted PV modules occupy an area of $186,000 \mathrm{~m}^{2}$, the agrivoltaics system is on an area of $40,000 \mathrm{~m}^{2}$ and the floating PV modules occupy an area of $3200 \mathrm{~m}^{2}$ on the $16,000 \mathrm{~m}^{2}$ swamp located in the north of the grounds. PV modules from polycrystalline cells were used in the plant and the current efficiency of the polycrystalline cells is about $16.7 \%$. An aerial view of the PV plant showing the PV modules and a $3400 \mathrm{~m}^{2}$ greenhouse is illustrated in Figure 8. 


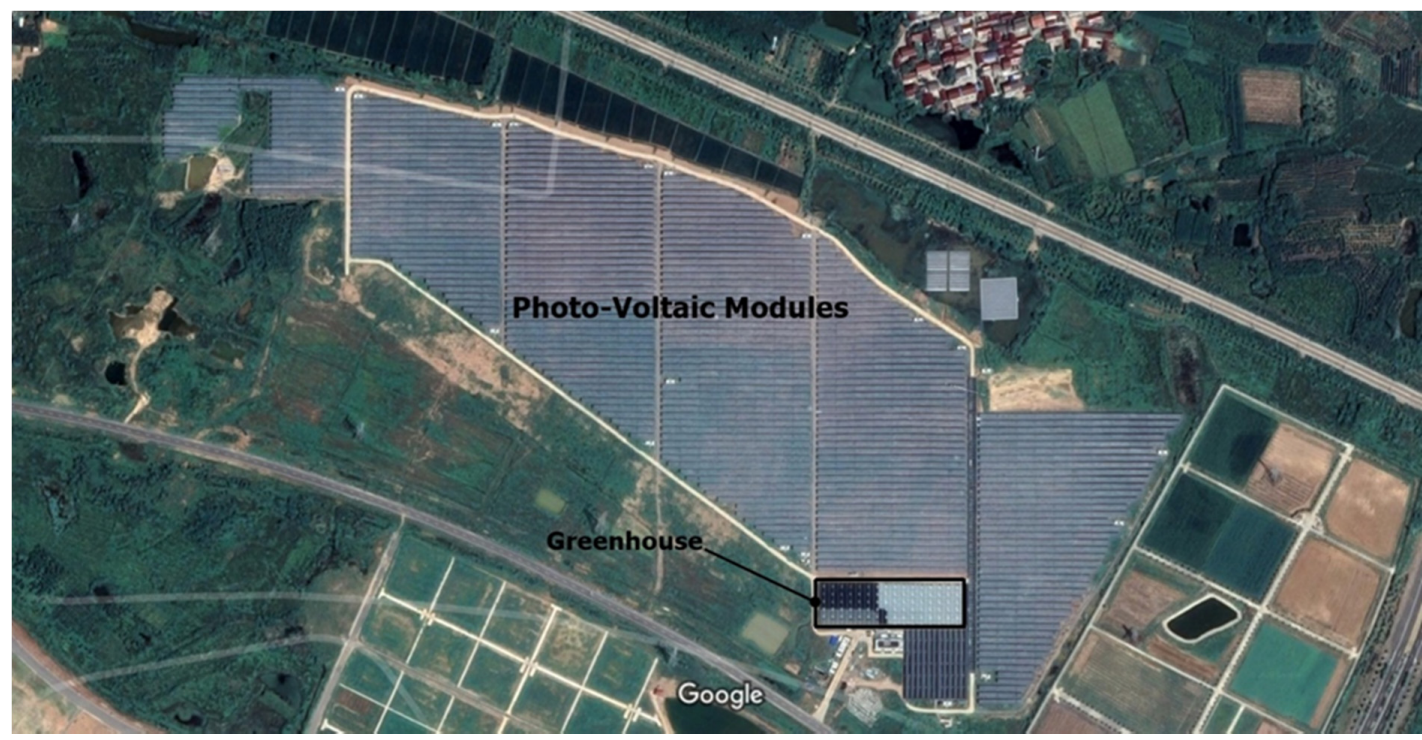

Figure 8. Aerial view of the Shenzhen Energy solar photovoltaics (PV) power plant [72].

The average monthly GHI for Baima is derived from the WorldClim dataset daily average GHI values and utilized to estimate the monthly potential electric generation power (potential GP), which is the technical solar potential of the land area occupied by the PV power plant. The estimated potential GP is thereafter illustrated alongside monthly actual electric generated power (actual GP) of the PV power plant for the years 2018 and 2019. The capacity of the solar PV plant was 19.05886 MW and 19.40606 MW in 2018 and 2019, respectively. A similar solar PV capacity is assumed. Despite this direct comparison, it is noteworthy that there are many factors that influence the amount of electric power evacuated, including: sunshine hours, cloud cover, weather (rain, snow, etc.), solar cell efficiency and so forth. Figure 9 illustrates the estimated monthly potential GP and the monthly actual GP. Monthly sunshine hours derived from daily sunshine hour values recorded at the location of the plant are also illustrated as they have an influence on the amount of electric power generated.

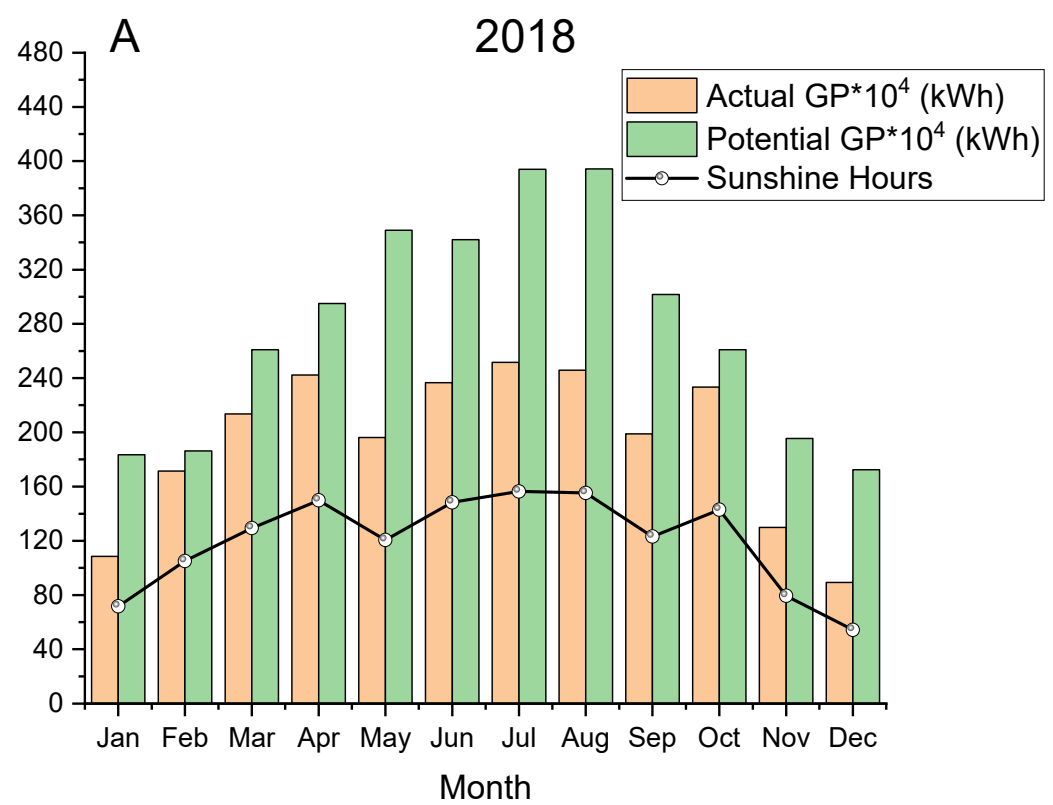

Figure 9. Cont. 


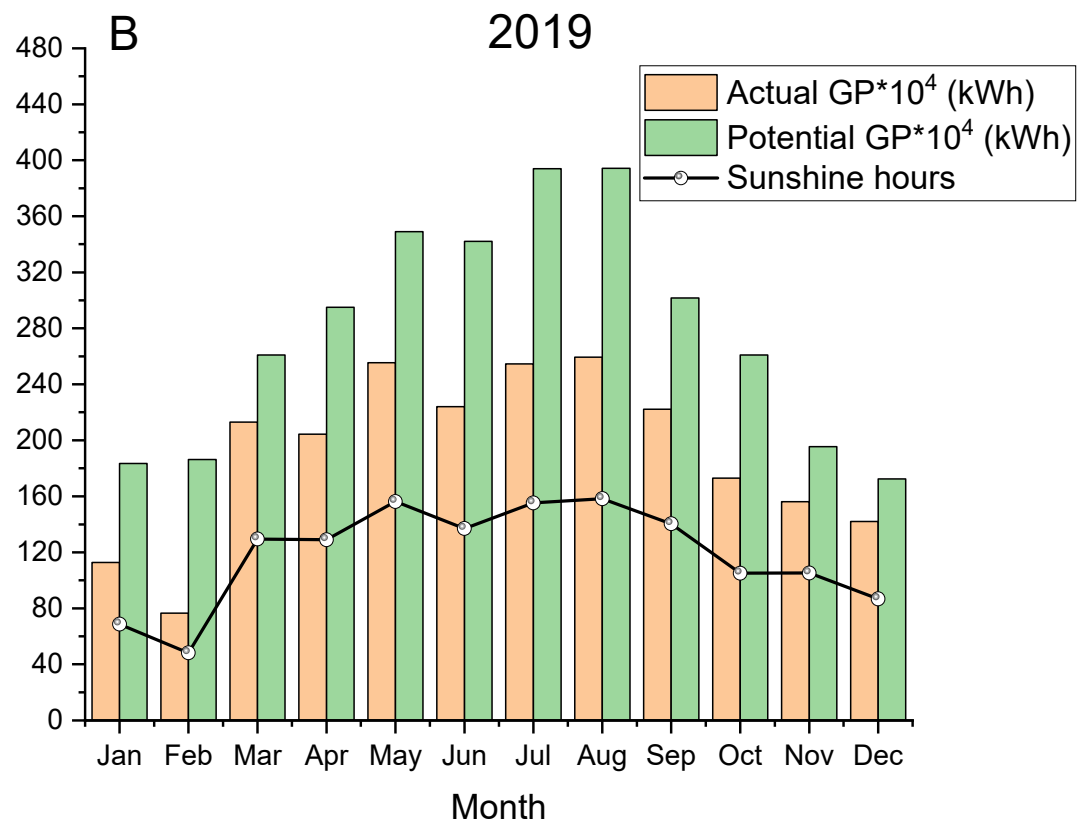

Figure 9. Potential generation power (GP) and actual GP of the solar PV power plant alongside monthly sunshine hours for: (A) 2018 and (B) 2019.

Figure 9 indicates that the estimated potential GP was about 1.08 to 1.93 times the actual GP in 2018, and 1.21 to 2.43 times the actual GP in 2019. The potential GP is a theoretical value and differs from the actual excavated solar energy on account of photoelectric losses and weather. In addition, solar radiation data play a significant role in the accuracy of the evaluated potential GP. Fick et al. [46] noted that solar radiation data had a particularly low number of stations meeting the highest criteria, thus, satellite-derived data were integrated. This may have resulted in accuracy issues in the model applied to obtain the WorldClim solar radiation data, which probably over- or underestimated the potential GP. Accuracy concerns in the solar radiation data highlight the significance of using local ground-based solar radiation measurements for the estimation of potential GP, as this would eliminate errors, as was noted by Clifton et al. [45].

As expected, the trend of the sunshine hours tracked the actual GP, with higher sunshine hours resulting in higher actual GP and lower sunshine hours leading to reduced actual GP. The significance of sunshine hours to the actual GP is evident in that, despite a higher solar capacity of $0.35 \mathrm{MW}$ in 2019, the actual GP in 2019 is slightly lower that the actual GP in 2018 on account of reduced sunshine hours.

The monthly energy consumption of the $3400 \mathrm{~m}^{2}$ greenhouse in 2019 is depicted in Figure 10.

The seasonal variation of energy consumption is significant as it provides information that is essential for greenhouse energy management. As can be seen in Figure 10, the peak periods with high energy consumption are mainly during the winter and summer period, with the lowest in the spring and autumn months.

As illustrated in Figure 10, the $3400 \mathrm{~m}^{2}$ greenhouse had an annual energy consumption of $47.82 \times 10^{4} \mathrm{kWh}$, which equates to a consumption of approximately $140 \mathrm{~kW} / \mathrm{m}^{2} / \mathrm{yr}$. This annual energy consumption is a mere $2.06 \%$ and $2.08 \%$ of the total actual GP of the PV plant in 2018 and 2019, respectively. The rest of the generated electricity is sold to the national grid, constituting the solar energy contribution to the energy mix in Jiangsu. 


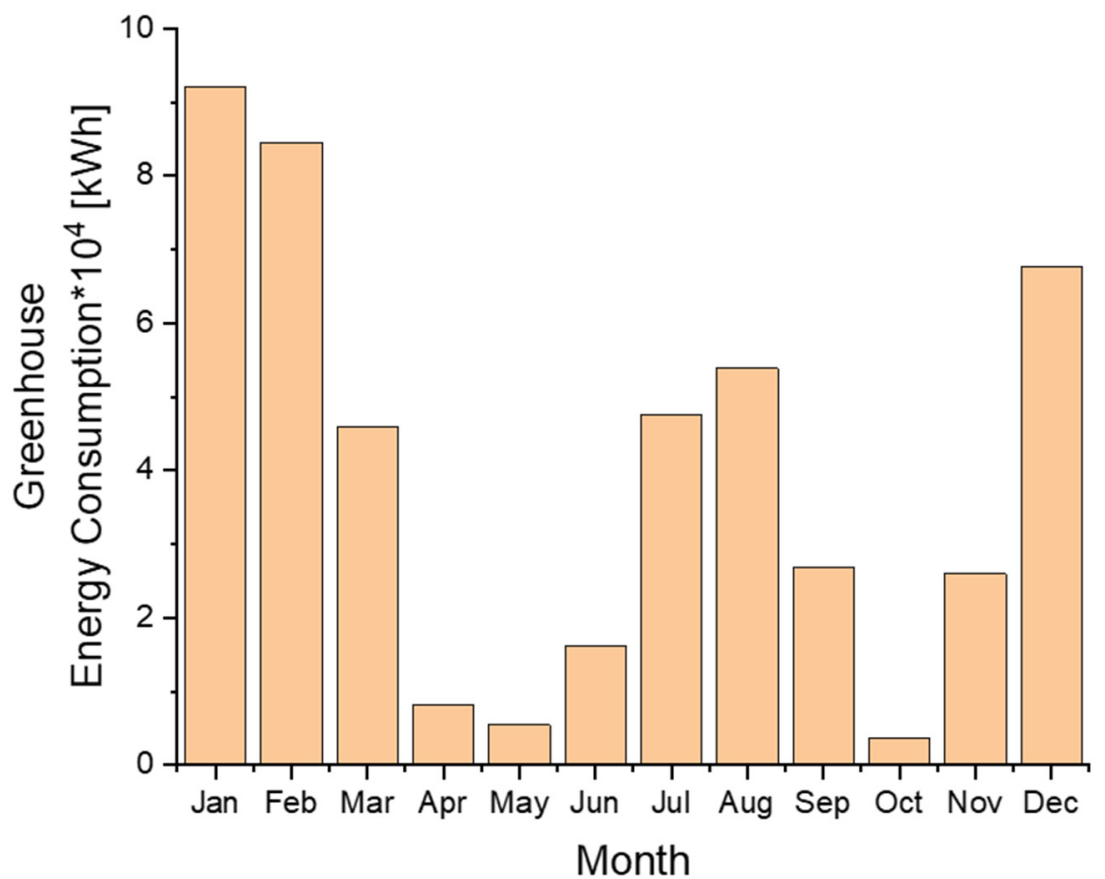

Figure 10. Monthly energy consumption of the $3400 \mathrm{~m}^{2}$ greenhouse in 2019.

Employing a similar greenhouse, a similar ventilation system installed in the greenhouses, utilizing just 30\% of generated electricity in 2019 and holding all other variables constant, a cluster of $15,3400 \mathrm{~m}^{2}$ greenhouses can be sustainably supported annually. It is commonplace in China to set up clusters of greenhouses as opposed to having one greenhouse with a large ground area. Greenhouses in the southern and eastern regions of China consume an estimated $300 \mathrm{MWh} / \mathrm{ha}$ /year of electricity derived from fossil fuelbased energy sources, for ventilation and cooling, and those in northern China consume an estimated 1499 tonnes to 2998 tonnes of coal annually to provide optimal plant growth conditions. In China, greenhouses are mainly concentrated in the YRDR, the Huanghai region, northwest regions and the Bohai Bay region. The YRDR accounts for approximately $20 \%$ of the total land area under horticultural cultivation in the entire country [73,74]. Adopting solar energy usage in the greenhouses located in the YRDR, as a replacement for fossil fuel-based energy sources, would: (1) mitigate against air pollution and environmental degradation, (2) provide solutions for current and future challenges of high energy costs and (3) enhance sustainable agricultural production systems. Nevertheless, policies that favor incentive programs will be pivotal to encourage growers to switch from fossil fuelbased energy sources. Moreover, the development of PV installation will allow proximity to the greenhouses in the YRDR; this will constitute part of the load demand, thereby reducing power losses due to long-distance electricity transmissions and mitigating the need to expand the power grid, as was the case with the PV power plant and the $3400 \mathrm{~m}^{2}$ greenhouse in this study.

\section{Conclusions}

In this study, a multi-criteria approach was applied to extract the suitable land area from the YRDR total land area using the best available geographical, social, environmental and cultural constraints data. Thereafter, the geographical and technical solar energy potential of the YRDR were estimated using high-resolution solar radiation data.

Despite the enormous solar energy potential estimated, it would be impossible to commission utility-scale solar installations on the entire suitable area calculated, nonetheless, the scale of available solar energy potential that can be exploited in the YRDR by the adoption of a combination of ground-mounted PV installations and agrivoltaics systems is provided in this research. 
The highlights of the research are summarized as follows:

(1) The YRDR is endowed with rich solar resources with geographical solar energy potential in the suitable areas varying spatially from $1446 \mathrm{kWh} / \mathrm{m}^{2}$ to $1658 \mathrm{kWh} / \mathrm{m}^{2}$, illustrating the sufficient solar energy resources available.

(2) The maximum solar capacity potential could be up to $4140.5 \mathrm{GW}$, which is equivalent to 98.85 times the total cumulative installed capacity in the YRDR at the end of 2019, showing the large potential that still exists for future development.

(3) The technical solar energy potential is very high, at an estimated value of $7550 \mathrm{TWh}$, which corresponds to 5.22 times the total electricity consumption in the YRDR in 2018, characterizing the significant potential available that can meet the YRDR power needs, turn the YRDR into an exporter of electricity and substantially mitigate $\mathrm{CO}_{2}$ emissions if the potential is fully realized.

(4) Jiangsu and Anhui provinces provide the most optimal areas for the construction of utility-scale solar PV installations as they have the highest geographical and technological solar energy potential.

(5) The disparities between actual GP and potential GP observed in the PV plant used as a case study highlight the significance of utilizing solar radiation data from local ground-based meteorological stations for the estimation of technical solar energy potential.

The results obtained in this study are promising and this methodological approach could be relevant in regions and countries in Sub-Saharan Africa, Southeast Asia and Latin America practicing intensive agriculture and facing the challenge of energy poverty but seeking to mitigate land competition while enhancing high energy and food production.

In future, an economic solar potential and life-cycle assessment of the proposed PV installations is recommended.

Author Contributions: Conceptualization, X.W. and M.R.O.O.; methodology, X.W. and M.R.O.O.; software, M.R.O.O.; validation, X.W. and A.A.; formal analysis, M.R.O.O. and A.A.; investigation, M.R.O.O. and A.A.; resources, X.W.; data curation, M.R.O.O. and A.A.; writing-original draft preparation, M.R.O.O.; writing-review and editing, X.W., A.A. and G.M.; visualization, M.R.O.O. and G.M.; supervision, X.W.; project administration, X.W.; funding acquisition, X.W. All authors have read and agreed to the published version of the manuscript.

Funding: This research was funded by:National Key R\&D Program of China, grant number 2019YFD 1001902. and National Key R\&D Program of China, grant number 2017YFD0701400.

Institutional Review Board Statement: Not applicable.

Informed Consent Statement: Not applicable.

Data Availability Statement: Publicly available datasets were analyzed in this study. This data can be found in the corresponding links provided in the reference section.

Acknowledgments: The authors would like to thank the management and staff of Shenzhen Energy for their invaluable support and assistance during the experimentation period. The authors are indeed grateful to the editors and anonymous reviewers for their invaluable suggestions, comments and helpful advice that improved the quality of this manuscript.

Conflicts of Interest: The authors declare no conflict of interest.

$\begin{array}{ll}\begin{array}{ll}\text { Abbreviations } \\ \text { YRDR }\end{array} & \text { Yangtze River Delta region } \\ \text { PV } & \text { photovoltaics } \\ \text { GP } & \text { technical solar potential; the potential electric generation power } \\ \text { GHI } & \text { global horizontal irradiance } \\ \text { potential GP } & \text { potential electric generation power } \\ \text { actual GP } & \text { actual electric generated power } \\ \text { NASA SSE } & \text { National Aeronautics and Space Administration Surface Meteorology and Solar } \\ & \text { Energy program }\end{array}$




\section{References}

1. Prakash, R.; Bhat, I.K. Energy, economics and environmental impacts of renewable energy systems. Renew. Sustain. Energy Rev. 2009, 13, 2716-2721.

2. Sampaio, P.G.V.; González, M.O.A. Photovoltaic solar energy: Conceptual framework. Renew. Sustain. Energy Rev. 2017, 74, 590-601. [CrossRef]

3. Razykov, T.M.; Ferekides, C.S.; Morel, D.; Stefanakos, E.; Ullal, H.S.; Upadhyaya, H.M. Solar photovoltaic electricity: Current status and future prospects. Sol. Energy 2011, 85, 1580-1608. [CrossRef]

4. United Nations. UNFCCC Conference of the Parties: Adoption of the Paris Agreement; FCCC/CP/2015/10Add.1; United Nations: Paris, France, 2015; pp. 1-32.

5. Fang, H.; Li, J.; Song, W. Sustainable site selection for photovoltaic power plant: An integrated approach based on prospect theory. Energy Convers. Manag. 2018, 174, 755-768. [CrossRef]

6. Colak, H.E.; Memisoglu, T.; Gercek, Y. Optimal site selection for solar photovoltaic (PV) power plants using GIS and AHP: A case study of Malatya Province, Turkey. Renew. Energy 2020, 149, 565-576. [CrossRef]

7. International Energy Agency (IEA). Photovoltaic Power Systems Programme, Report IEA-PVPS T1-37:2020. Available online: https:/ /iea-pvps.org/wp-content/uploads/2020/04/IEA_PVPS_Snapshot_2020.pdf (accessed on 11 November 2020).

8. Sun, Y.-W.; Hof, A.; Wang, R.; Liu, J.; Lin, Y.-J.; Yang, D.-W. GIS-based approach for potential analysis of solar PV generation at the regional scale: A case study of Fujian Province. Energy Policy 2013, 58, 248-259. [CrossRef]

9. Sun, Y.; Wang, R.; Li, J.; Liu, J. GIS-based multiregional potential evaluation and strategies selection framework for various renewable energy sources: A case study of eastern coastal regions of China. Energy Sci. Eng. 2017, 5, 123-140. [CrossRef]

10. Yang, Q.; Huang, T.; Wang, S.; Li, J.; Dai, S.; Wright, S.; Wang, Y.; Peng, H. A GIS-based high spatial resolution assessment of large-scale PV generation potential in China. Appl. Energy 2019, 247, 254-269. [CrossRef]

11. Zhang, Y.; Ren, J.; Pu, Y.; Wang, P. Solar energy potential assessment: A framework to integrate geographic, technological, and economic indices for a potential analysis. Renew. Energy 2020, 149, 577-586. [CrossRef]

12. Liu, J.; Xu, F.; Lin, S. Site selection of photovoltaic power plants in a value chain based on grey cumulative prospect theory for sustainability: A case study in Northwest China. J. Clean. Prod. 2017, 148, 386-397. [CrossRef]

13. Charabi, Y.; Gastli, A. PV site suitability analysis using GIS-based spatial fuzzy multi-criteria evaluation. Renew. Energy 2011, 36, 2554-2561. [CrossRef]

14. Doorga, J.R.; Rughooputh, S.D.; Boojhawon, R. Multi-criteria GIS-based modelling technique for identifying potential solar farm sites: A case study in Mauritius. Renew. Energy 2019, 133, 1201-1219. [CrossRef]

15. Yushchenko, A.; De Bono, A.; Chatenoux, B.; Patel, M.K.; Ray, N. GIS-based assessment of photovoltaic (PV) and concentrated solar power (CSP) generation potential in West Africa. Renew. Sustain. Energy Rev. 2018, 81, 2088-2103. [CrossRef]

16. Dinesh, H.; Pearce, J.M. The potential of agrivoltaic systems. Renew. Sustain. Energy Rev. 2016, 54, 299-308. [CrossRef]

17. Marrou, H.; Guilioni, L.; Dufour, L.; Dupraz, C.; Wéry, J. Microclimate under agrivoltaic systems: Is crop growth rate affected in the partial shade of solar panels? Agric. For. Meteorol. 2013, 177, 117-132. [CrossRef]

18. Marrou, H.; Wéry, J.; Dufour, L.; Dupraz, C. Productivity and radiation use efficiency of lettuces grown in the partial shade of photovoltaic panels. Eur. J. Agron. 2013, 44, 54-66. [CrossRef]

19. Schindele, S.; Trommsdorff, M.; Schlaak, A.; Obergfell, T.; Bopp, G.; Reise, C.; Braun, C.; Weselek, A.; Bauerle, A.; Högy, P. Implementation of agrophotovoltaics: Techno-economic analysis of the price-performance ratio and its policy implications. Appl. Energy 2020, 265, 114737. [CrossRef]

20. Barron-Gafford, G.A.; Pavao-Zuckerman, M.A.; Minor, R.L.; Sutter, L.F.; Barnett-Moreno, I.; Blackett, D.T.; Thompson, M.; Dimond, K.; Gerlak, A.K.; Nabhan, G.P. Agrivoltaics provide mutual benefits across the food-energy-water nexus in drylands. Nat. Sustain. 2019, 2, 848-855. [CrossRef]

21. Adeh, E.H.; Good, S.P.; Calaf, M.; Higgins, C.W. Solar pV power potential is Greatest over croplands. Sci. Rep. 2019,9 , 11442. [CrossRef]

22. Wu, J.; Wei, Y.D.; Li, Q.; Yuan, F. Economic transition and changing location of manufacturing industry in China: A study of the Yangtze River Delta. Sustainability 2018, 10, 2624. [CrossRef]

23. The State Council of the People's Republic of China. Outline of the Yangtze River Delta Regional Integration Development Plan. 2019. Available online: www.gov.cn/zhengce/2019-12/01/content_5457442.htm (accessed on 12 November 2020).

24. Movellan, J. Japan Next-Generation Farmers Cultivate Crops and Solar Energy. 2013. Available online: https://www. renewableenergyworld.com/2013/10/10/japan-next-generation-farmers-cultivate-agriculture-and-solar-energy/ (accessed on 12 December 2020).

25. Jain, A.; Das, P.; Yamujala, S.; Bhakar, R.; Mathur, J. Resource Potential and Variability Assessment of Solar and Wind Energy in India. Energy 2020, 211, 118993. [CrossRef]

26. Phadke, A.; Bharvirkar, R.; Khangura, J. Reassessing Wind Potential Estimates for India: Economic and Policy Implications; Lawrence Berkeley National Lab. (LBNL): Berkeley, CA, USA, 2011.

27. Al Garni, H.Z.; Awasthi, A. Solar PV power plant site selection using a GIS-AHP based approach with application in Saudi Arabia. Appl. Energy 2017, 206, 1225-1240. [CrossRef] 
28. National Ministry of Land and Resources of the People's Republic of China. Photovoltaic Power Plant Project Land Use Control Indicators. 2016. Available online: http://mlr.gov.cn/zwgk/zfgkml/gkml_9184/201512/t20151211_1391339.htm (accessed on 13 November 2020).

29. International Centre for Tropical Agriculture. Hole-Filled Seamless SRTM Data Version 4. Available online: http:/ / srtm.csi.cgiar. org/ (accessed on 1 November 2020).

30. GADM. Available online: https://gadm.org/download_country_v3.html (accessed on 1 November 2020).

31. WWF Global Lakes and Wetlands Database. Available online: https://www.worldwildlife.org/pages/global-lakes-andwetlands-database (accessed on 1 November 2020).

32. UNEP-WCMC; IUCN. Protected Planet: The World Database on Protected Areas (WDPA) [Online], September 2020; UNEP-WCMC and IUCN: Cambridge, UK, 2020. Available online: https:/ / www.protectedplanet.net (accessed on 1 November 2020).

33. Natural Earth Urban Areas. Available online: https://www.naturalearthdata.com/downloads/50m-cultural-vectors/50murban-areas / (accessed on 1 November 2020).

34. DIVA-GIS Spatial Data Download. Available online: https://www.diva-gis.org/datadown (accessed on 1 November 2020).

35. ESA Data User Element. Available online: http://due.esrin.esa.int/page_globcover.php (accessed on 1 November 2020).

36. Lacerda, J.S.; Van Den Bergh, J.C. Diversity in solar photovoltaic energy: Implications for innovation and policy. Renew. Sustain. Energy Rev. 2016, 54, 331-340. [CrossRef]

37. Tyagi, V.; Rahim, N.A.; Rahim, N.; Jeyraj, A.; Selvaraj, L. Progress in solar PV technology: Research and achievement. Renew. Sustain. Energy Rev. 2013, 20, 443-461. [CrossRef]

38. Green, M.A.; Dunlop, E.D.; Levi, D.H.; Hohl-Ebinger, J.; Yoshita, M.; Ho-Baillie, A.W. Solar cell efficiency tables (version 54). Prog. Photovolt. Res. Appl. 2019, 27, 565-575. [CrossRef]

39. Li, D.; Liu, G.; Liao, S. Solar potential in urban residential buildings. Sol. Energy 2015, 111, 225-235. [CrossRef]

40. Khan, G.; Rathi, S. Optimal site selection for solar PV power plant in an Indian state using geographical information system (GIS). Int. J. Emerg. Eng. Res. Technol. 2014, 2, 260-266.

41. Broesamle, H.; Mannstein, H.; Schillings, C.; Trieb, F. Assessment of solar electricity potentials in North Africa based on satellite data and a geographic information system. Sol. Energy 2001, 70, 1-12. [CrossRef]

42. Djebbar, R.; Belanger, D.; Boutin, D.; Weterings, E.; Poirier, M. Potential of concentrating solar power in Canada. Energy Procedia 2014, 49, 2303-2312. [CrossRef]

43. Gastli, A.; Charabi, Y. Siting of large PV farms in Al-Batinah region of Oman. In Proceedings of the 2010 IEEE international energy conference, Manama, Bahrain, 18-22 December 2010; pp. 548-552.

44. National Renewable Energy Laboratory (NREL). PVWatts®Calculator; Alliance for Sustainable Energy, LLC.: Golden, CO, USA, 2020. Available online: http:/ / pvwatts.nrel.gov (accessed on 12 December 2020).

45. Clifton, J.; Boruff, B.J. Assessing the potential for concentrated solar power development in rural Australia. Energy Policy 2010, 38, 5272-5280. [CrossRef]

46. Fick, S.E.; Hijmans, R.J. WorldClim 2: New 1-km spatial resolution climate surfaces for global land areas. Int. J. Climatol. 2017, 37, 4302-4315. [CrossRef]

47. International Renewable Energy Agency. IRENA Unleashing the Solar Potential in ECOWAS: Seeking Areas of Opportunity for Grid-Connected and Decentralised PV Applications; An Opportunity-Based Approach; International Renewable Energy Agency: Abu Dhabi, UAE, 2013.

48. Anwarzai, M.A.; Nagasaka, K. Utility-scale implementable potential of wind and solar energies for Afghanistan using GIS multi-criteria decision analysis. Renew. Sustain. Energy Rev. 2017, 71, 150-160. [CrossRef]

49. Ong, S.; Campbell, C.; Denholm, P.; Margolis, R.; Heath, G. Land-Use Requirements for Solar Power Plants in the United States; National Renewable Energy Lab. (NREL): Golden, CO, USA, 2013.

50. China Energy Council. Available online: https:/ / cec.org.cn/ (accessed on 19 November 2020).

51. The State Council of the People's Republic of China. Three-Year Action Plan to Win the "Blue Sky Defence War". 2018. Available online: http:/ / www.gov.cn/zhengce/2018-07/13/content_5306045.htm (accessed on 11 November 2020).

52. The State Council of the People's Republic of China. Air Pollution Prevention and Control Action Plan. 2013. Available online: http:/ / www.gov.cn/zwgk/2013-09/12/content_2486773.htm (accessed on 11 November 2020).

53. China Statistical Yearbook 2019. Available online: http://www.stats.gov.cn/tjsj/ndsj/2019/indexeh.htm (accessed on 19 November 2020).

54. He, G.; Kammen, D.M.J.R.E. Where, when and how much solar is available? A provincial-scale solar resource assessment for China. Renew. Energy 2016, 85, 74-82. [CrossRef]

55. Bergin, M.H.; Ghoroi, C.; Dixit, D.; Schauer, J.J.; Shindell, D.T. Large reductions in solar energy production due to dust and particulate air pollution. Environ. Sci. Technol. Lett. 2017, 4, 339-344. [CrossRef]

56. Elminir, H.K.; Ghitas, A.E.; Hamid, R.; El-Hussainy, F.; Beheary, M.; Abdel-Moneim, K.M. Effect of dust on the transparent cover of solar collectors. Energy Convers. Manag. 2006, 47, 3192-3203. [CrossRef]

57. Li, X.; Wagner, F.; Peng, W.; Yang, J.; Mauzerall, D.L. Reduction of solar photovoltaic resources due to air pollution in China. Proc. Natl. Acad. Sci. USA 2017, 114, 11867-11872. [CrossRef]

58. Mani, M.; Pillai, R. Impact of dust on solar photovoltaic (PV) performance: Research status, challenges and recommendations. Renew. Sustain. Energy Rev. 2010, 14, 3124-3131. [CrossRef] 
59. Huang, T.; Wang, S.; Yang, Q.; Li, J. A GIS-based assessment of large-scale PV potential in China. Energy Procedia 2018, 152, 1079-1084. [CrossRef]

60. He, G.; Zhou, C.; Li, Z. Review of self-cleaning method for solar cell array. Procedia Eng. 2011, 16, 640-645. [CrossRef]

61. Vrînceanu, A.; Grigorescu, I.; Dumitrașcu, M.; Mocanu, I.; Dumitrică, C.; Micu, D.; Kucsicsa, G.; Mitrică, B. Impacts of photovoltaic farms on the environment in the Romanian plain. Energies 2019, 12, 2533. [CrossRef]

62. Amaducci, S.; Yin, X.; Colauzzi, M. Agrivoltaic systems to optimise land use for electric energy production. Appl. Energy 2018, 220, 545-561. [CrossRef]

63. Ravi, S.; Macknick, J.; Lobell, D.; Field, C.; Ganesan, K.; Jain, R.; Elchinger, M.; Stoltenberg, B. Colocation opportunities for large solar infrastructures and agriculture in drylands. Appl. Energy 2016, 165, 383-392. [CrossRef]

64. Hassanpour Adeh, E.; Selker, J.S.; Higgins, C.W. Remarkable agrivoltaic influence on soil moisture, micrometeorology and water-use efficiency. PLoS ONE 2018, 13, e0203256. [CrossRef] [PubMed]

65. Cossu, M.; Murgia, L.; Ledda, L.; Deligios, P.A.; Sirigu, A.; Chessa, F.; Pazzona, A. Solar radiation distribution inside a greenhouse with south-oriented photovoltaic roofs and effects on crop productivity. Appl. Energy 2014, 133, 89-100. [CrossRef]

66. Emmott, C.J.; Röhr, J.A.; Campoy-Quiles, M.; Kirchartz, T.; Urbina, A.; Ekins-Daukes, N.J.; Nelson, J. Organic photovoltaic greenhouses: A unique application for semi-transparent PV? Energy Environ. Sci. 2015, 8, 1317-1328. [CrossRef]

67. Skoplaki, E.; Palyvos, J.A. Operating temperature of photovoltaic modules: A survey of pertinent correlations. Renew. Energy 2009, 34, 23-29. [CrossRef]

68. Marrou, H.; Dufour, L.; Wery, J. How does a shelter of solar panels influence water flows in a soil-crop system? Eur. J. Agron. 2013, 50, 38-51. [CrossRef]

69. Spencer, R.S.; Macknick, J.; Aznar, A.; Warren, A.; Reese, M.O. Floating photovoltaic systems: Assessing the technical potential of photovoltaic systems on man-made water bodies in the continental United States. Environ. Sci. Technol. 2018, 53, 1680-1689. [CrossRef]

70. Zhou, Y.; Chang, F.-J.; Chang, L.-C.; Lee, W.-D.; Huang, A.; Xu, C.-Y.; Guo, S. An advanced complementary scheme of floating photovoltaic and hydropower generation flourishing water-food-energy nexus synergies. Appl. Energy 2020, 275, 115389. [CrossRef]

71. Cagle, A.E.; Armstrong, A.; Exley, G.; Grodsky, S.M.; Macknick, J.; Sherwin, J.; Hernandez, R.R. The Land Sparing, Water Surface Use Efficiency, and Water Surface Transformation of Floating Photovoltaic Solar Energy Installations. Sustainability 2020, $12,8154$. [CrossRef]

72. Google Maps. Available online: https://www.google.com/maps/@31.6249933,119.1768603,833m/data=!3m1!1e3 (accessed on 1 November 2020).

73. Odhiambo, M.; Wang, X.; de Antonio, P.; Shi, Y.; Zhao, B. Effects of Root-Zone Temperature on Growth, Chlorophyll Fluorescence Characteristics and Chlorophyll Content of Greenhouse Pepper Plants Grown under Cold Stress in Southern China. Russ. Agric. Sci. 2018, 44, 426-433. [CrossRef]

74. Odhiambo, M.R.O.; Abbas, A.; Wang, X.; Elahi, E. Thermo-Environmental Assessment of a Heated Venlo-Type Greenhouse in the Yangtze River Delta Region. Sustainability 2020, 12, 10412. [CrossRef] 